\title{
Investigation of the Effects of Eucalyptus camaldulensis on Performance of Neighbouring Crop Productivity in Western Amhara, Ethiopia
}

\author{
Melkamu Alebachew ${ }^{1}$, Tadele Amare ${ }^{2}$, Minale Wendie ${ }^{3}$ \\ ${ }^{1}$ Amhara Agricultural Research Institute (ARARI), Adet Agricultural Research Center, Bahir Dar, Ethiopia \\ ${ }^{2}$ Adet Agricultural Research Center (AARC), Bahir Dar, Ethiopia \\ ${ }^{3}$ Amhara Regional Agricultural Research Institute (ARARI), Bahir Dar, Ethiopia \\ Email: ${ }^{*}$ yetmwork2000@gmail.com, tadele17b@yahoo.com
}

Received 22 February 2015; accepted 9 March 2015; published 13 March 2015

Copyright (C) 2015 by authors and OALib.

This work is licensed under the Creative Commons Attribution International License (CC BY). http://creativecommons.org/licenses/by/4.0/

(c) (i) Open Access

\section{Abstract}

The study was conducted on investigating effects of Eucalyptus camaldulensis on the performance of adjacent crop productivity for the benefits over adverse effects of it versus different land uses in district Mecha of Western Amhara region, Ethiopia. This research was carried out with the aim to test the performance of neighbouring crops grown near $E$. camaldulensis on the effects on plant growth performance and grain yield. Eucalypts has many important uses and a reliable source of cash income for farm households. Despite the apparent benefits, there have been public reactions against Eucalypts planting, and of course the growers insist on planting for it is fast growing and biomass production. A simple plot experiment was laid away from tree stand replicated three times to each field for both crops to understand the effect of Eucalypts on adjacent crop productivity at different locations and random samples were taken. SAS (version 9) and descriptive statistics were employed. The study through key informants' interview assured that most local farmers perceived the effect of Eucalypts on field crop performance nearby it. Crop yield and yield components showed a reduction from tree stand. Plant biomass, height, plant count, and grain yield of Zea mays and Panicum miliaceum decreased with distance to Eucalypts stand. Maize grain yield and biomass reduction was around 6.6 and 15 fold difference from tree stand to $20 \mathrm{~m}$ (control) sampling points respectively; whereas, for finger millet, grain yield difference was around 2.9 fold from tree stand. Yield and yield parameters suppression were ended at a distance of 14 to $20 \mathrm{~m}$ away from tree stand. This was not significantly $(P<0.05)$ different in yield and biomass between 20 and $25 \mathrm{~m}$. Therefore, poor performances of adjacent crops, particularly the most important parameter grain yield, were due to competition for growth resources between Eucalypts and adjacent food crops. The scientific research has also confirmed the potential effect of Eucalypts on

*Corresponding author.

How to cite this paper: Alebachew, M., Amare, T. and Wendie, M. (2015) Investigation of the Effects of Eucalyptus camaldulensis on Performance of Neighbouring Crop Productivity in Western Amhara, Ethiopia. Open Access Library Journal, 2: e992. http://dx.doi.org/10.4236/oalib.1100992 
adjacent crops cultivated side by side. Altogether, it is recommended that field crops should be cultivated as far an average distance greater to about $20 \mathrm{~m}$ (center of farm) from Eucalyptus stand. Moreover, when planted on farms, Eucalypts should be restricted to sites where neighbouring crop productivity will not be adversely influenced.

\title{
Keywords
}

\section{E. camaldulensis, Neighbouring Crops, Grain Yield, Woodlots, Crop Performance, Adverse Effects}

\author{
Subject Areas: Agricultural Science, Plant Science
}

\section{Introduction}

Eucalyptus camaldulensis Dehnh (River Red Gum) was first introduced to Ethiopia during the reign of Emperor Menelik II (1868-1907) in 1895 [1]. He recognized the fact in Ethiopia that planting of exotic trees commenced through the establishment of block plantations surrounding the major cities to supply fuel wood for urban populations. His major aim was to alleviate shortage of wood-based demands specially to solve the critical shortage of fuelwood and construction material in the capital and other towns in the country. By the mid-1970s, Eucalyptus plantations owned by large landholders had covered approximately 91,000 hectares in Addis Ababa and surrounding highland towns [2]. Then, it was noted that alone E. camaldulensis and E. globulus covered 250,000 hectares [3] [4]. From the total exotic species introduced, these two species were successful in solving wood demand to some extent. Until the revolution in 1974, resources of forest products in rural areas were limited to natural forest exploitation with limited planting of Eucalyptus on farmlands.

The genus Eucalyptus is in the family Myrtacea. The species is second to pines in global importance as plantation trees. In the tropics and subtropics it is the most widely planted genus. Globally, Eucalypts comprises more than 900 species and unknown hybrids and varieties [5]. This species in Ethiopia in general and in Amhara region in particular is planted and adapted to grow across a wide range of agro-ecological conditions; some hardy species grow in semi-arid areas, while others are able to grow on marshy and swampy sites. E. camaldulensis is cultivated in large areas in Amhara region and is ranked as the first tree used as a cash crop, and also the most popular species used for construction and fuelwood source. The principal benefits of Eucalyptus are their wood due to its fast growth, short rotation, and high yielding per unit area and year [2] [6] [7]. It is potentially productive and more economical grown in different forms from woodlot at household level to large plantation projects. However, afforestation with Eucalyptus is controversial because it is said that it has adverse effects on the ecology and crop growth resources. Besides, it is also said when Eucalyptus is grown in conditions with adequate supplies of water and nutrients, or in managed plantations at favourable sites, water-use efficiency and productivity are high. Compared with many other species, E. camaldulensis performs high productivity on infertile soil and hot temperatures [8]. The problem of population pressure in recent years has contributed to the intensive use of marginal land which is intact and reserved for forest plantations. As population pressure increased, resources have been exploited excessively. The need to expand cultivated land for crop production and shortages of fuel biomass has led to removal of well-adapted, nutrient additive indigenous trees. In addition, cropping areas including near the vicinity of Eucalyptus plantations have expanded into marginal lands, such as steep slopes and mountainous areas, and fallow periods have been shortened or abandoned [9].

This change in land use has made farmers to plant crops near Eucalypts plantations, even though there is a perception that Eucalyptus adversely affects crop productivity through competition for growth resources. Despite the expansion of cultivated lands, food insecurity remains unsolved because agricultural productivity has been seriously eroded by resource depletion through several factors. In spite of the apparent benefits, there have been some adverse public reactions against Eucalyptus planting practices. The criticisms are based on a range of technical, ecological, social and economic arguments [10]. Most of the criticisms are unfair, biased, nationalistic or emotional [6]. It was noted that the criticisms could also be equally applied to other exotic tree species. Although quantitative evidence is scanty, there has been a perception that this practice adversely affects crop productivity [11]. In contrast, farmers showed great enthusiasm and interest for adopting Eucalyptus as a big project for 
improving their livelihood strategy due to its fast growth, ability to coppicing and tolerance to browsing. They have been planting at homesteads, woodlots, farm boundaries, on road borders, and on croplands.

As such, Eucalyptus has been a common species introduced during past agroforestry efforts [11]. In recent years, single rows of Eucalyptus planted along agroforestry niches have become a dominant feature of central highlands of Ethiopia including the study area (Mecha wereda), which is located around the source and head of Blue Nile within Lake Tana watershed. Increasing plantations would create competition for land area between agricultural food crops and E. camaldulensis. Thus, this research was undertaken with the aim to test the performance of neighbouring crops such as finger millet (Panicum miliaceum) and maize (Zea mays L.) grown nearby E. camaldulensis on the consequent effects on plant growth performance and grain yield.

The results of the study can effectively create awareness for the community concerning specific effects of $E$. camaldulensis on performance and yield of neighbouring crops on the given environment and agroforestry practice. Moreover, land management planners can use this information in their decisions on land use in the study area where tree planting niches can be assigned; and to understand the particular choices made by farmers concerning Eucalyptus as an enterprise of income generation.

\section{Materials and Methods}

\subsection{Description of the Study Area}

The study was conducted in district Mecha of West-Gojjam Zone in the western Amhara Region. It was specifically carried out in 5 "Kebele" administrations. The entire study site is geographically situated between $11^{\circ} 10^{\prime} \mathrm{N}$ to $11^{\circ} 25^{\prime} \mathrm{N}$ Latitude and $37^{\circ} 02^{\prime} \mathrm{E}$ to $37^{\circ} 17^{\prime} \mathrm{E}$ Longitude and ranges from 1800 to $3200 \mathrm{~m}$.a.s.l with a mean annual rainfall of $1560 \mathrm{~mm}$ and a mean daily temperature between $16^{\circ} \mathrm{C}$ and $20^{\circ} \mathrm{C}$. Mecha is one of the 13 districts of the zone located at $525 \mathrm{~km}$ northwest of Addis Ababa and $38 \mathrm{~km}$ west of Bahir Dar, the capital of the region. It is an agriculturally potential district located at the head source of Blue Nile River within the Lake Tana Watershed. Nitisol is the dominant soil type in the area and actually considered fertile soils. They are deep, welldrained, red, tropical soils and stable soils with favourable physical properties [12]. In addition, the deep porous and stable soil structure permits deep rooting and make conducive environment for the production of food crops such as maize and finger millet, and trees like E. camaldulensis. The cropping system is mixed agriculture. Food crops common in the area are, Eragrostis teff, Zea mays L., finger millet (Panicum miliaceum), Guizotia abyssinica/Noug/, Rape seed, white lupine, field pea, beans, pepper, potato, pumpkin, Gomen zer and many other vegetables, spices, and fruits bearing shrubs and trees are cultivated throughout the study area. In spite of the fact that the diversified potential of crop productivity farmers has widely planted E. camaldulensis computing croplands, it grows fast and requires less care. Tree planting niches identified in the study area are at woodlots, cropland boundary planting, homesteads, road borders, live fence, and churches under an agroforestry practice and plantations to fulfill the needs for fuel wood, construction and also to generate income [7] [13].

\subsection{Methodology}

\subsubsection{Planting Materials and Data Collection Methods}

The overall impact of Eucalyptus trees on crop production and moisture storage was assessed through interviews with key informants. Forty interested, knowledgeable and active farmers were selected purposively and interviewed in three representative Kebele Adminstrations (Kudmi, Enguty and Ambomesk), which are dominated by individually owned Eucalyptus woodlots. The primary purpose of these interviews was to gather information concerning the history and background of Eucalyptus and to provide direction concerning the fundamental issues and questions to be answered experimentally. The answers from respondents were expressed in percentages for comparison. Since the interviewed farmers were very familiar with their environment, accurate indigenous knowledge concerning Eucalyptus tree with their environment was definitely collected. Interviewing of farmers was also carried out using semi-structured questionnaire.

The study was carried out for four years in 2009 through 2012 during the main single-rainy seasons. The test crops were maize and finger millet which are the major crops to perform well in Nitisol including the studied sites [12]. Maize variety BH540 a late maturing one, has good grain filling ability in the area, and is characterized by reddish tassel where as finger millet seeds were offered from Adet Agricultural Research Center. On farm food crops were planted nearby E. camaldulensis with a similar tree age to orientations in Northern, Southern, 
Eastern and Western aspects. In all locations, simple-plot based experimental sites of size $10 \times 25\left(250 \mathrm{~m}^{2}\right)$ were utilized for and each plot was subdivided into seven plots of yield strata corresponding at 1, 2, 3, 5, 7, 10 and $15 \mathrm{~m}$ away from tree stand to both crops for the years 2009 and 2010; while, for years 2011 and 2012 with very close monitoring of the experimental sites, data were randomly taken at nine yield strata corresponding at 2 , $5,8,11,14,17,20,23$, and $25 \mathrm{~m}$ distances laid away from tree stand replicated three times to each field. For crop parameters, data collected at $20 \mathrm{~m}$ distance from tree stand was used as a control value owing to it was $5 \mathrm{~m}$ beyond tree shade casting and is center of the farm.

In order to check the entire effects of Eucalyptus on crop performance for the factors explained previously, plant height, dry biomass, grain yield and other yield parameters were harvested per $1 \times 1\left(1 \mathrm{~m}^{2}\right)$ and $2 \times 2\left(4 \mathrm{~m}^{2}\right)$ area at treatments in to the finger millet and maize fields respectively from tree stand and were compared. Measurements of all parameters were taken after half of November through half of December, 135 days after planting. The harvested maize ears were husked, shelled, sun dried, then weighed; and grain moisture was determined by the "Dickey John Moisture Tester" and yield was converted to $15 \%$ moisture content. Finger millet was also sun-dried by spreading the straw out on a flat surface as farmers do. Straw and yield was separated after drying and were then weighed based on plots.

\subsubsection{Data Analysis}

Analysis of variance using SAS (version 9) was performed to determine effects of E. camaldulensis on treatments and on parameters of both crops to the entire tree orientations [14]. All analyses were performed at a significance level of 0.05 , i.e., statistical differences were determined by ANOVA employing a $95 \%$ level of confidence. Descriptive statistical procedures were also applied.

\section{Results}

\subsection{Farmer's Perceptions about Influences of Eucalyptus camaldulensis on Crop Performance Vis-a-Vis the Scientific Evidence}

Many of key informants $(90 \%)$ were males ranging in age from 30 to 60 years old with an education level that varies from religious and adult education to 10th grade or higher. In addition, over 97 and 80 percent are orthodox Christian with a married status respectively (Table 1). Most of them interviewed in the study area complained about influence and impacts of Eucalyptus on neighbouring food crops for the low performance due to

Table 1. Key informants' demographic expression in the study sites $(\mathrm{N}=40)$.

\begin{tabular}{|c|c|c|c|c|c|}
\hline \multirow{2}{*}{$\begin{array}{c}\text { Demographic information } \\
\text { Sex }\end{array}$} & \multicolumn{5}{|c|}{$\%$ of key informants } \\
\hline & $\mathrm{Ma}$ & 90) & & $(10)$ & \\
\hline \multirow{2}{*}{ Age in years } & $30-45$ & $46-60$ & $61-75$ & $>75$ years age & \\
\hline & (70) & (15) & (12.5) & $(2.5)$ & \\
\hline \multirow[t]{2}{*}{ Educational level } & Illiterate & $\begin{array}{l}\text { Religious \& adult } \\
\text { education }\end{array}$ & grade 1 - 4 & grade $5-8$ & $>9$ th grade \\
\hline & $(12.5)$ & (45) & (20) & (10) & $(12.5)$ \\
\hline \multirow[b]{2}{*}{ Religious } & & Muslim & & & \\
\hline & Orthodox (97.5) & (2.5) & Other $(0)$ & & \\
\hline \multirow{2}{*}{ Marital status of } & Single & Married & Divorced & Widowed & Other \\
\hline & (5) & (80) & (10) & (5) & (0) \\
\hline \multirow{2}{*}{ Number of HHs } & $2 \mathrm{HHs}$ & $3 \mathrm{HHs}$ & $4 \mathrm{HHs}$ & 5 HHS & \\
\hline & (15) & $(17.5)$ & (20) & $(47.5)$ & \\
\hline
\end{tabular}

Note: $\mathrm{HHs}=$ households. 
competition in soil moisture and soil nutrients as well as shade casting effect. In addition, the most commonly planted tree species in the studied sites was E. camaldulensis (100\%). However, they thought that land used for planting Eucalyptus can still be used for other crops after the stumps have been removed. They do not think that Eucalyptus will help to improve water conditions but improve soil. So far, farmers saw only the adverse effects of Eucalyptus. They perceive Eucalyptus as having economic rather than ecological benefits. From scientific research point of view, Eucalyptus, like Acacia and a number of other tree crops, reduces moisture, nutrients, and affects neighboring crops, where only moisture and nutrients are in short supply. Tree planting in the area was most commonly for income generation (100\%), fast growth (79\%), construction and fuel wood (47\%), and less upkeep (75\%) (Table 2). From the farmers' point of view to the common crops grown in the area, the highly susceptible crops are finger millet (91\%), maize (75\%), Niger seed (54\%), teff $(46 \%)$, and others $(43 \%)$ because of shade casting effect and competition of resources.

All key informants owned land ranging from 0.2 to 3 hectares despite most of them (37.5\%) owned farms of 0.75 to 1.25 ha followed by 0.2 to 0.75 ha of size (25\%). All of them utilized their land for a combination of agriculture and tree planting. As shown in (Table 2), many of the farmers planted E. camaldulensis was at niches along farm boundary (55\%), woodlots (34.5\%), and at homesteads $(4.5 \%)$. The farm sizes covered in hectares with trees by farmers responses was up to the size of $0.25(28 \%), 0.50(42 \%), 0.75(20 \%)$, and $2(3 \%)$ respectively.

\subsection{Experimental Findings about Effects of Eucalyptus on Neighbouring Food Crops}

\section{Effects of Eucalyptus camaldulensis on Finger Millet and on Maize Performance}

In Figures 2(a)-(c), plant height, biomass and grain yield of finger millet (Panicum miliaceum) are given as a function of distance from the stand of E. camaldulensis. The measurements were considered in the four major directions with respect to tree orientation in the entire studied sites. The effect on the crop parameters near the

Table 2. Key informant's activities on their land and their perception about impact of Eucalyptus.

\begin{tabular}{|c|c|c|c|c|c|}
\hline \multirow{4}{*}{$\begin{array}{c}\text { Farmers' land size and land use } \\
\text { Possession of land } \\
\text { Land size in total in hectares }\end{array}$} & \multicolumn{5}{|c|}{$\%$ of respondents } \\
\hline & \multicolumn{3}{|c|}{ Yes $(100)$} & \multicolumn{2}{|c|}{ No $(0)$} \\
\hline & $0.2-0.75$ & $0.75-1.25$ & $1.25-2$ & $2-2.5$ & $2.5-3$ \\
\hline & (25) & $(37.5)$ & (20) & $(12.5)$ & (5) \\
\hline Land planted Eucalyptus in hectares & Up to $0.25(28)$ & Up to $0.5(42)$ & Up to $0.75(20)$ & Up to $1(7)$ & Up to $2(3)$ \\
\hline Most activities by farmers & $\begin{array}{l}\text { Crop production } \\
\quad(100)\end{array}$ & $\begin{array}{c}\text { Grazing } \\
\text { \& livestock } \\
\quad(100)\end{array}$ & $\begin{array}{l}\text { Tree planting } \\
\text { (100) }\end{array}$ & $\begin{array}{c}\text { Off-farm } \\
\text { activities } \\
\quad(16)\end{array}$ & $\begin{array}{c}\text { On-farm } \\
\text { activities } \\
(25)\end{array}$ \\
\hline Planted tree/shrub species by farmers & Eucalyptus (100) & \multicolumn{4}{|c|}{ Others (20) } \\
\hline Niches of Eucalyptus planting & $\begin{array}{l}\text { Boundary } \\
\text { planting (55) }\end{array}$ & $\begin{array}{l}\text { Woodlots } \\
(34.5)\end{array}$ & On croplands (3) & Homesteads (4.5) & $\begin{array}{l}\text { On marginal } \\
\text { land (3) }\end{array}$ \\
\hline $\begin{array}{l}\text { Tree management activities } \\
\text { carried out by key informants }\end{array}$ & Thinning (17) & $\begin{array}{l}\text { Pruning and } \\
\text { lopping }(20)\end{array}$ & Coppicing (90) & \multicolumn{2}{|l|}{ Pollarding (65) } \\
\hline $\begin{array}{l}\text { Farmers' reasons for } \\
\text { Eucalyptus planting }\end{array}$ & $\begin{array}{l}\text { Construction \& } \\
\text { fuelwood (47) }\end{array}$ & $\begin{array}{l}\text { Cash income } \\
\quad(100)\end{array}$ & $\begin{array}{l}\text { Fast growth } \\
\quad \text { (79) }\end{array}$ & $\begin{array}{l}\text { Less upkeep } \\
\quad(75)\end{array}$ & $\begin{array}{l}\text { Live capital asset } \\
\text { (35) }\end{array}$ \\
\hline \multirow{2}{*}{\multicolumn{2}{|c|}{$\begin{array}{l}\text { Effect on crop production and moisture } \\
\text { content }\end{array}$}} & Yes & & \multicolumn{2}{|c|}{ No } \\
\hline & & $(100)$ & & \multicolumn{2}{|c|}{ (0) } \\
\hline $\begin{array}{l}\text { Eucalyptus affects crop growing } \\
\text { by which influencing mechanism? }\end{array}$ & $\begin{array}{l}\text { Moisture } \\
\text { competition (27) }\end{array}$ & $\begin{array}{c}\text { Nutrient } \\
\text { competition (32) }\end{array}$ & $\begin{array}{l}\text { Shading effect for } \\
\text { light (65) }\end{array}$ & $\begin{array}{c}\text { Effect at } \\
\text { grain filling (35) }\end{array}$ & $\begin{array}{c}\text { Tree mg't } \\
\text { problem (66) }\end{array}$ \\
\hline Resistance difference by crops & \multicolumn{3}{|c|}{ Yes (63) } & \multicolumn{2}{|c|}{ No (37) } \\
\hline $\begin{array}{l}\text { Level of effect of Eucalyptus on different } \\
\text { neighbouring crops \& their resistance }\end{array}$ & Teff (37) & F. millet (9) & Maize (18) & Noug (12) & Others (13) \\
\hline $\begin{array}{l}\text { Effect of Eucalyptus on neighbouring } \\
\text { crops \& level of susceptible crops }\end{array}$ & Finger millet (91) & Maize (75) & Teff (46) & Noug (54) & Other (43) \\
\hline
\end{tabular}


tree obviously faired much worse than farther away in all aspects of tree orientation. Figures 3(a)-(c) also showed a similar trend for all plant height, biomass and grain yield of maize (Zea mays) as a function of distance from the tree stand. There were around 6.6 and 15 fold difference in maize grain yield and biomass for the 2 and $20 \mathrm{~m}$ (center of farm) sampling points respectively as a function of distances from Eucalyptus tree stand. Irrespective of the figures, this was also true for finger millet as there was around 2.9 fold difference in grain yield. The yield and biomass between 20 and $25 \mathrm{~m}$ was not significantly $(\mathrm{P}<0.05)$ different to yield and yield parameters during the studying years as well as locations.

Regarding Eucalyptus orientation on the major directions, the crop parameters showed difference that the highest effect of tree orientation was observed when it was in Eastern ward side followed by Southern ward side than the other two (Figure 2(a), Figure 2(b), Figure 3(a) and Figure 3(b)). This could be because competition for the before-noon sun-light by shading is an additional phenomenon rather than other common crop growing resources casting in eastern aspects (Figure 1(a) and Figure 1(b)). In research, it was noted that E. camaldulensis is a light-demanding species [8].

\section{Discussion}

The results of this study showed that Eucalyptus camaldulensis was planted by farmers in niches of agroforestry and plantation areas. The niches were on boundary plantings, woodlots, homesteads and plantation. It played an important role in income generation but with a remarkable impact on neighbouring crop performance (Table 2) and is in line with the works of [11] [15]. Based on measurements and experimental results of crop yield and yield parameters, variable results were obtained. It showed that there was a profound similarity among the different trial sites tested with respect to Eucalyptus stand laid-down to four major directions. Plant height, biomass weight and grain yield of finger millet and maize were given as a function of distance from Eucalyptus stand (Figures 1-3). Obviously, the effect on yield and yield parameters of finger millet near the tree faired much worse than farther away (Figures 2(a)-(c)). It was also shown that similar trends for maize grain yield and yield components as a function of distance from tree stand (Figures 3(a)-(c)). The study was supported by the works of [13] [16] [17]. It was found that there were around 6.6 and 15 fold difference in maize grain yield and biomass for the 2 and $20 \mathrm{~m}$ (center of farm) sampling points respectively from tree stand. It was also true for finger millet as there was around 2.9 fold difference in grain yield. Grain yield and biomass for both crops between 20 and $25 \mathrm{~m}$ was not significantly $(\mathrm{P}<0.05)$ different over years and locations as in line with the report by [18].

Regarding the negative effect of Eucalyptus on both finger millet and maize; plant height, biomass, grain yield and other parameters were ended at 14 to $20 \mathrm{~m}$ yield stratum from tree stand. This assured that closed to tree stand at $2 \mathrm{~m}$ through $20 \mathrm{~m}$ sampling distance, plant height of maize was reduced $30.4 \%$ over $69.5 \%$; biomass was reduced $7 \%$ over $92.9 \%$ and plant count $28.9 \%$ over $71 \%$; while the most important parameter, the maize grain yield was greatly reduced $17.8 \%$ over $82.1 \%$ with significant difference in yield (LSD $=6.64 \mathrm{q} / \mathrm{ha}$ and $\mathrm{CV}=7.6$ ) respectively (Figure 3(a)-(c)). In addition, the finding was also shown that similar trends were observed for finger millet grain yield and yield components as a function of distance from tree line. Here, plant height was reduced 18.4 over $81.5 \%$, biomass 34.6 over $65.3 \%$ and grain yield 6.3 over $93.7 \%$ respectively for parameter comparison at 2 through $20 \mathrm{~m}$ with significant difference in yield (LSD $=2.91$ quin-
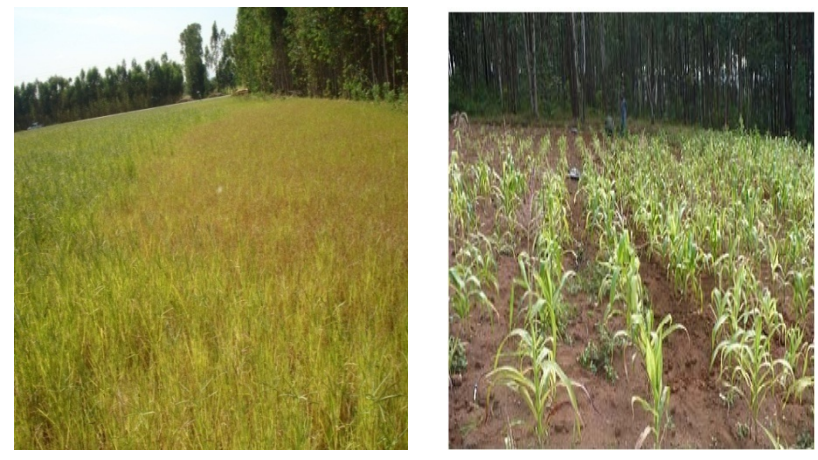

(a)

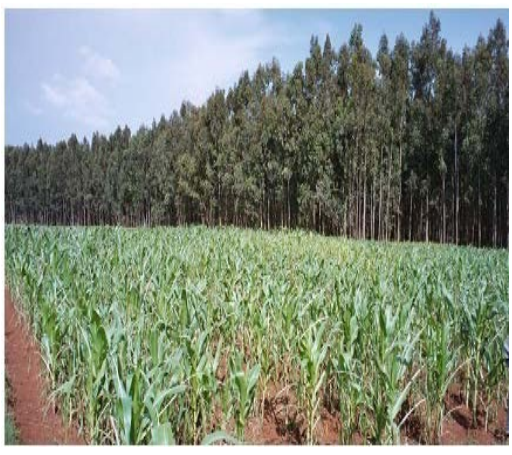

(b)

Figure 1. (a) (Finger millet) and (b) (Maize) grown nearby E. camaldulensis in Eastern Orientation/aspect/. 




(a)

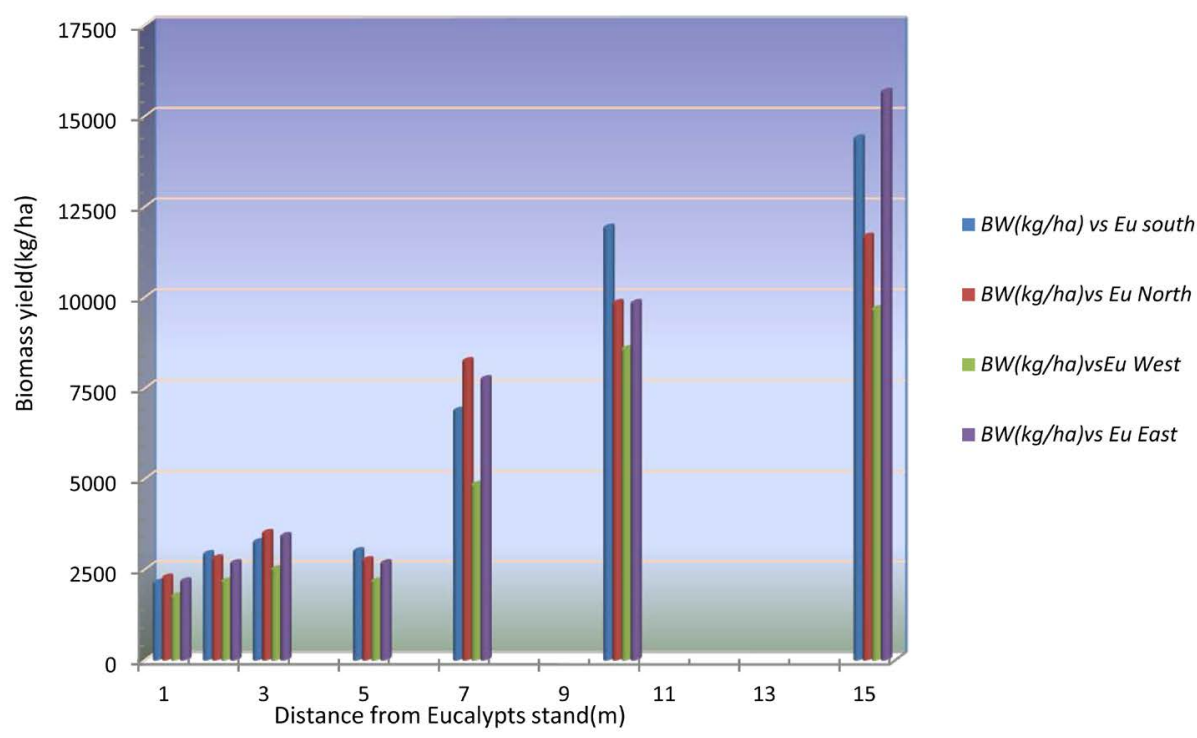

(b)

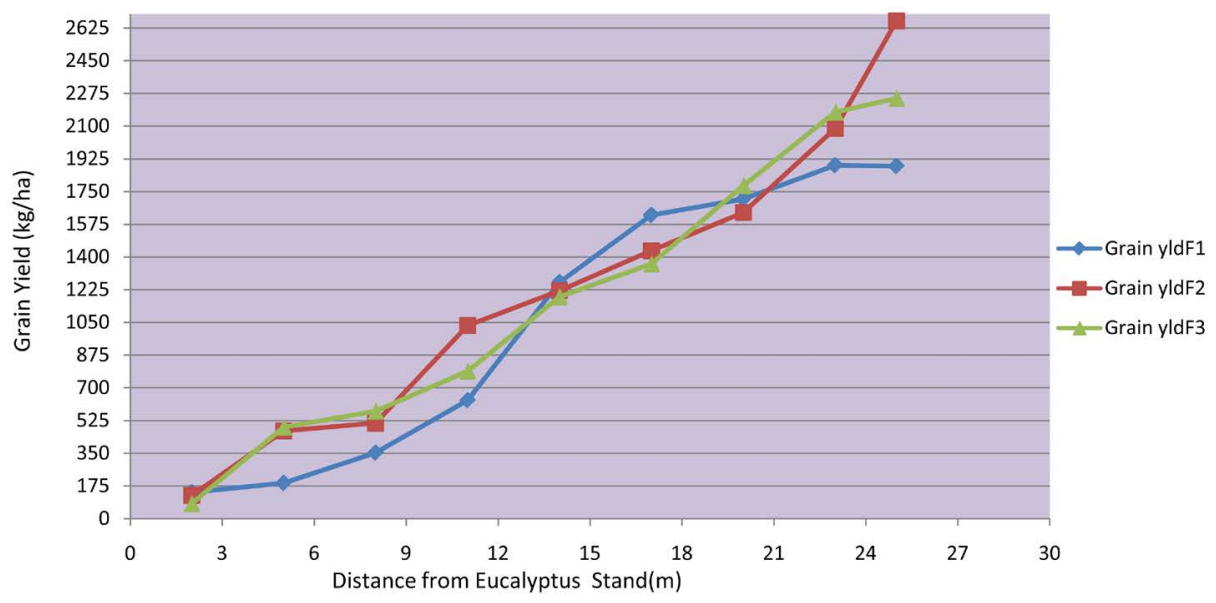

(c)

Figure 2. Finger millet plant height (a); biomass (b) and grain yield (c) comparison as a function of distance away from E. camaldulensis stand. The measurements of all parameters were taken in North, South, East, and West tree orientations after half of November through December. NB. F1, F2 and F3 in the legend entry showed fields 1,2 and 3 at which the research has been done. 


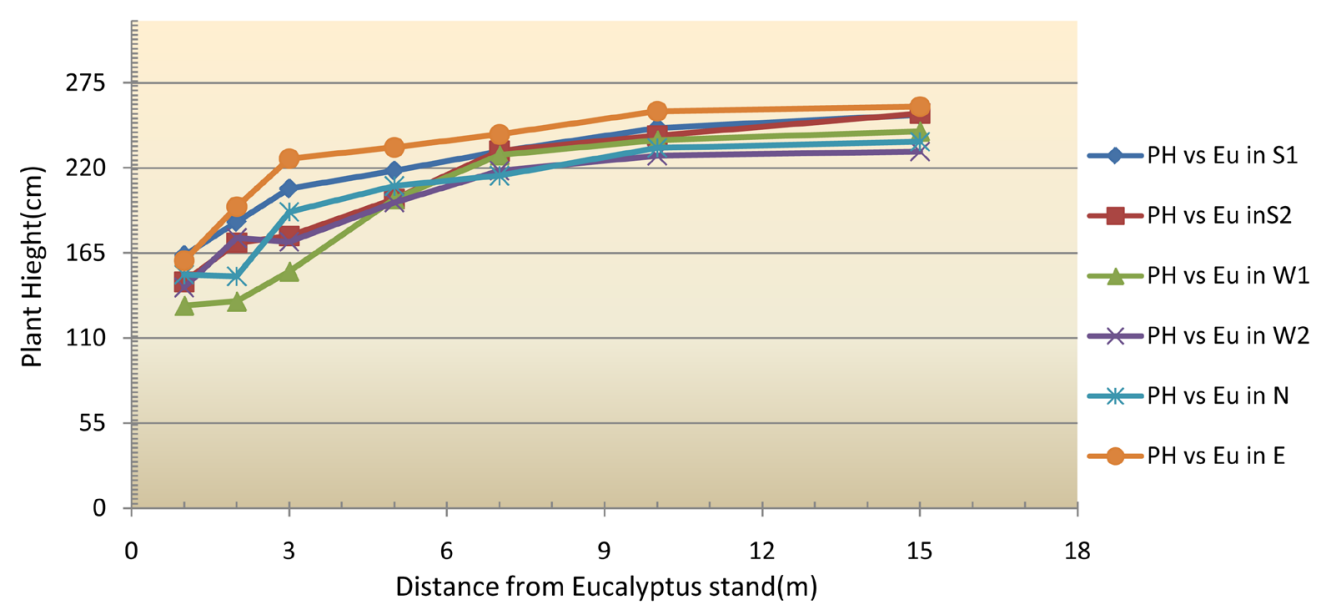

(a)

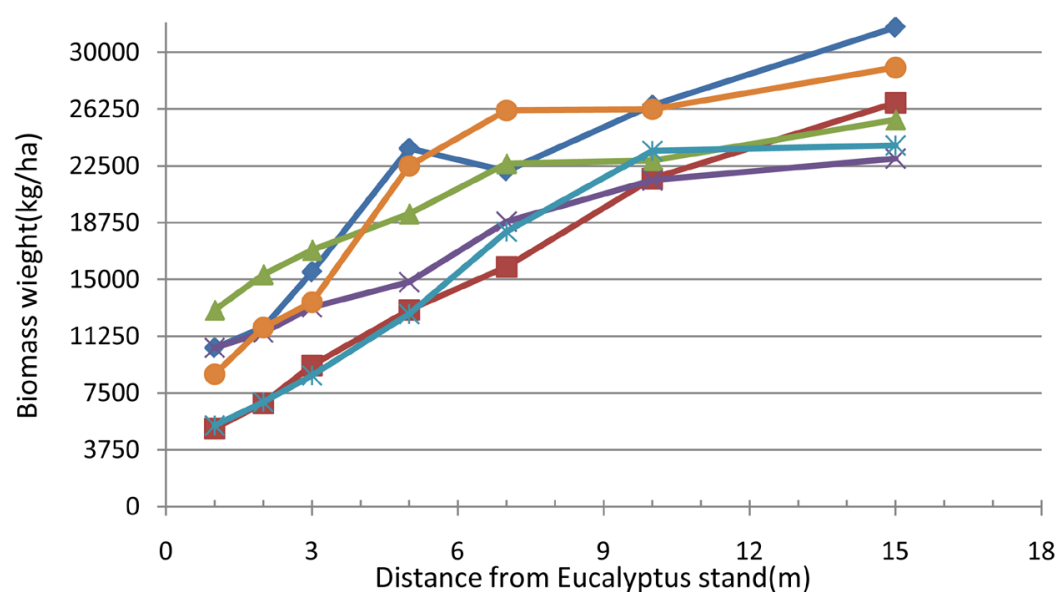

$\prec$ BW vs Eu S1

-BW vs Eu S2

- BW vs Eu W1

$\leftarrow$ BW vs Eu W2

- BW vs Eu N

- BW vs Eu E

(b)

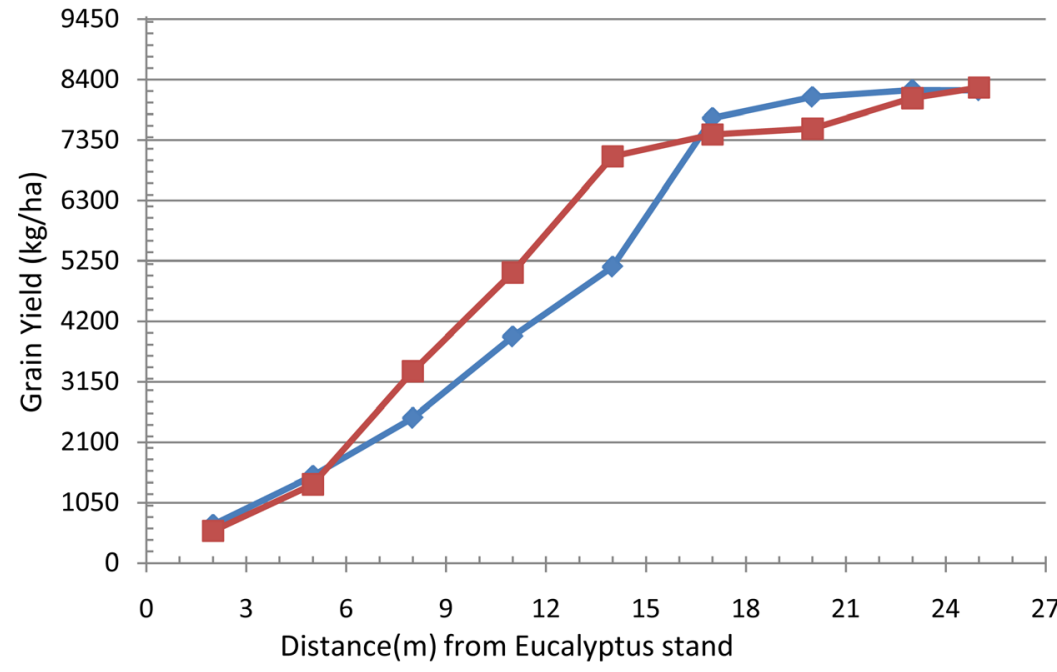

$\sim$ Gyld vs Eu E1

Gyld vs EuE2

(c)

Figure 3. Maize plant height (a); biomass (b) and grain yield (c) comparison as a function of distance away from Eucalyptus camaldulensis stand. The measurements of all parameters were taken in North, South, East, and West direction after half of November through December. (a) NB. $S_{1}, S_{2}, W_{1}, W_{2}, N$ and E stands for directions and numbers for different locations; (b) NB. $\mathrm{S}_{1}, \mathrm{~S}_{2}, \mathrm{~W}_{1}, \mathrm{~W}_{2}, \mathrm{~N}$ and $\mathrm{E}$ stands for directions and numbers for locations; (c) NB. $F_{1}$ and $F_{2}$ in the legend entry showed fields 1 and 2. 
tals/ha and CV $=10.9$ ) (Figures 2(a)-(c)). These results are supported by other works. [16] in Etiopia reported that the effect of Eucalyptus on wheat ended at $8-16 \mathrm{~m}$. [19] in Tanzania reported a decrease of $42.9 \%$ for height, $74.6 \%$ for biomass of maize affected by the adjacent tree. Odhiambo et al. (2001) in Kenya found that reductions of crop yield were greatest (more than $40 \%$ ) close to trees. As we have already noted, Eucalyptus reduced crop yields on plots adjacent to woodlots or boundary planting rows of the tree and often there was no grain yield nearby the stand in the studied sites. It is in agreement to our study that the reduction from control (at $20 \mathrm{~m}$ ) were $39.1 \%, 85.9 \%$ and $64.3 \%$ for maize, and $63.1 \%, 30.7 \%$, and $87.4 \%$ for finger millet in plant height $(\mathrm{cm})$, biomass $(\mathrm{kg} / \mathrm{ha})$ and grain yield $(\mathrm{kg} / \mathrm{ha})$ respectively. [19] in Tanzania reported a decrease of $42.9 \%$ for height, $74.6 \%$ for maize biomass affected by the adjacent tree. Hence, the negative impacts of Eucalyptus can be minimized provided that the choice of species matched, site and of management of the stands are appropriate [10] [20] [21].

As it was ensured experimentally, both finger millet and maize plant performs poorly in its yield and yield components when E. camaldulensis orientation was in Eastern and Southern ward side than the other two (Figures 2(a)-(c) and Figures 3(a)-(c)). These might be greatly determined by light intensity that is important to get energy for whatever performances the crops do for shading is an additional phenomenon rather than competition with tree for moisture and nutrients. The shading effect is more pronounced if the neighboring grain crops are in west, north, and south and east directions from tree line respectively (Figure 2 and Figure 3). Therefore, both crops planted to tree proximity in the west direction were more seriously affected due to light shortage (Figure 2 and Figure 3). Due to shading and competition for water and nutrients, the yield and yield components close to tree stand was not as good as they are further away from the stand as supported by [22]. However, E.camaldulensis cast less shade than other broadleaved trees because their leaves naturally are held vertically downwards on the twigs and their crowns are often narrow. [23], based on the work of Jensen, concluded that there was no evidence to suggest that the effects of eucalypts on the associated crop are different from any other kind of tree when planted in agroforestry. Evidence since then does not alter this conclusion but in disagreement with this study. Hence, it is worthwhile to note that E.camaldulensis shade is characteristically patchy because the leaves usually hang downwards; entailing that shading is not a major problem. Key informants perceived that maize and finger millet yield is depressed by adjacent Eucalyptus planting although most farmers grew it badly (Table 2).

\section{Conclusions and Recommendation}

The study showed that the effect of Eucalypts on grain yield and yield components performance variation from tree stand obviously faired much worse than farther away. Finger millet and Maize yield and yield parameters suppression were ended at a distance of 14 to $20 \mathrm{~m}$ yield stratum away from the stand. This work showed that there was around 6.6 fold maize grain yield difference from the stand as compared with the control plot and so did for finger millet. The Eastern and Southern orientations were more pronounced. Therefore, poor performances of adjacent crops, particularly the most important parameter grain yield, were due to competition for growth resources between Eucalyptus and adjacent food crops. The study supports the idea that planting E. camaldulensis in association with agricultural crops can be against production in long term, and hence has an influencing effect on adjacent crop productivity. The scientific research has also confirmed the potential effect of E. camaldulensis on adjacent crops cultivated together.

In the contrary, farmers showed great enthusiasm and interest for expanding land areas for Eucalypus around crop farms and kept on cultivating it to meet their increasing woodfuel demand and income generation due to its fast growth, significant amount of biomass, ability to repeat coppicing and tolerance to browsing. Altogether, the studied results lead that agricultural crops should be cultivated as far a distance greater than about $20 \mathrm{~m}$ from $E$. camaldulensis stand. Until its introduction, however, Eucalyptus seems to be widely planted in Ethiopia as that of in the study areas. As a concluding remark, it appears that there are no profound reasons not to continue $E u$ calyptus planting in the region. To minimize the negative impacts and enhance the ecological and socioeconomic importance of planting Eucalyptus, selection of the appropriate site and management methods is very important. Moreover, when planted on farms, Eucalyptus should be restricted to appropriate sites with proper management and utilization so that it will not adversely influence neighbouring crop productivity.

\section{Acknowledgements}

The authors would like to thank to Amhara Region Agricultural Research Institute (ARARI) Forestry/Agrofo- 
restry Technology Supply Directorate especially to Dr. Teshome Tesma without whose managerial, technical and financial support, the challenges of this activity would not be completed. We authors would also like to express our thanks to the farmers at Ambomesk, Enguty and othe Kebele Administrations of Mecha district for their information and cooperation during data collection and experimental area support without any land rent.

\section{References}

[1] Von Breitenbach, F. (1961) Exotic Trees in Ethiopia. Ethiopian Forestry Review, 2, 19-38.

[2] Pohjonen, V. and Pukkala, T. (1990) Which Eucalypt Grows Best in Ethiopian Highlands? Journal of Biomass and Bioenergy, 1, 193-195.

[3] Tsegaye, B. (1996) Utilization of Sawn Boards from Young Eucalyptus Plantation Timber Grown in Ethiopia. Ph.D. Thesis, SLU, Uppsala.

[4] Turnbull, J.W. (1999) Eucalyptus Plantations. New Forests, 17, 37-52. http://dx.doi.org/10.1023/A:1006524911242

[5] Boland, D.J., Brooker, M.I.H., Chippendale, G.M., Hall, N., Hyland, B.P.M. and Johanson, R.D. (2006) Forest Trees of Australia. CSIRO, Melbourne.

[6] Davidson, J. (1989) The Eucalyptus Dilemma, Arguments for and against Eucalypt Planting in Ethiopia. Forestry Research Center Seminar Note Series 1, Addis Ababa.

[7] Zegeye, H. (2010) Environmental and Socio-Economic Implications of Eucalyptus in Ethiopia. In: Gil, L., Tadesse, W., Tolosana, E. and López, R., Eds., Proceedings of the Conference on Eucalyptus Species Management, History, Status and Trends in Ethiopia, Ethiopian Institute of Agricultural Research, Addis Ababa, 184-205.

[8] CSIRO (2004) www.anbg.gov.au/cpbr/WfHC/Eucalyptus-camaldulensis/index.html

[9] Jouquet, P., Bernared-Reversat, F., Botticelli, N., Orange, D., Rouland-Lefervre, C., Tran Duc, T. and Podwojewski, P. (2007) Influence of Changes in Land Use and Earthworm Activities on Carbon and Nitrogen Dynamics in a Steep Land Ecosystem in Northern Vietnam. Vietnam, 44, 69-77.

[10] FAO (Food and Agriculture Organization) (1988) The Eucalypt Dilemma. FAO, Rome.

[11] Kidanu, S., Mamo, T. and Stroosnijder, L. (2005) Biomass Production of Eucalyptus Boundary Plantations and Their Effect on Crop Productivity on Ethiopian Highland Vertisols. Agroforestry Systems, 63, 281-290.

[12] FAO (2001) State of World's Forests. Food and Agriculture Organization, Rome.

[13] Jagger, P. and Pender, J. (2003) The Role of Trees for Sustainable Management of Less-Favored Lands: The Case of Eucalyptus in Ethiopia. Forest Policy and Economics, 5, 83-95.

[14] SAS Institute (2001) SAS/STAT User's Guide. Version 9.0, SAS Institute, Cary.

[15] Nair, P.K.R. (1993) An Introduction to Agro Forestry Practices. Kluwer Academic Publishers, Dordrecht.

[16] Kidanu, S. (2004) Allelopathic Potential of Eucalyptus globulus in a Tree-Cropproduction System on Highland Vertisols in Ethiopia. Ph.D. Thesis, WUA, Amsterdam, 91-108.

[17] Chanie, T., Collick, A.S., Adgo, E., Lehmann, C.J. and Steenhuis, T.S. (2009) Eco Hydrological Impacts of Eucalyptus in the Semi Humid Ethiopian Highlands: The Lake Tana Plain. Journal of Hydrology and Hydromechanics, 61, 21-29. http://dx.doi.org/10.2478/johh-2013-0004

[18] Chanie, T., Collick, A.S., Adgo, E., Lehmann, C.J. and Steenhuis, T.S. (2013) Eco-Hydrological Impacts of Eucalyptus in the Semi Humid Ethiopian Highlands: The Lake Tana Plain. Journal of Hydrology and Hydromechanics, 61, 21-29.

[19] Chamshama, S.A.O. and Nwonwu, F.O.C. (2004) Forest Plantations in Sub-Saharan Africa. Sokoine University of Agriculture, Morogoro.

[20] Senbeta, F. (1998) Native Woody Species Regeneration under the Canopy of Tree Plantations at Munessa-Shashemene Forest Project Area, Southern Oromia, Ethiopia. Master's Thesis, Swedish University of Agricultural Sciences, Skinnskatteberg.

[21] Moges, Y. (1998) The Role of Exotic Plantation Forests in Fostering the Regeneration of Native Trees in an Afromontane Forest Area in Ethiopia. Master's Thesis, Wageningen Agricultural University, Wageningen.

[22] Teketay, D. (2000) Facts and Experiences on Eucalypts in Ethiopia and Elsewhere: Ground for Making Wise and Informed Decision. Walia, 21, 25-46.

[23] Poore, M.E.D. and Fries, C. (1985) The Ecological Effects of Eucalyptus. FAO Forestry Paper Series 59, FAO, Rome. 